\title{
EKSISTENSI AGAMA SHINTO DALAM PELAKSANAAN MATSURI DI JEPANG
}

\author{
Sri Dewi Adriani
}

Japanese Department, Faculty of Letters, Bina Nusantara University, Jl. Kemanggisan Ilir III No. 45, Kemanggisan/Palmerah, Jakarta Barat 11480, dewiadriani@yahoo.com

\begin{abstract}
Japan is one of the nations having an extensive historical culture, as well as the system of faith or religion. The existence of religion, as a part of their life, has been streaming from the ancient time (pre-modern) up to present. The implementation of their religious life is very unique and fascinating. Other remarkable issues is about the tight relationship among the religions especially Shinto with the festival performances which is held in Japan along the seasons.

Keywords: religion, festival, traditional, Shinto, matsuri

ABSTRAK

Jepang adalah salah satu negara di dunia yang memiliki sejarah kebudayaan yang panjang, termasuk di antaranya adalah sistem kepercayaan atau agama. Keberadaan agama sebagai bagian dari kehidupan masyarakat telah berlangsung sejak masa pra modern hingga saat ini. Pelaksaan kehidupan beragama di Jepang berlangsung unik dan menarik. Hal lain yang cukup menarik adalah adanya hubungan yang erat di antara agama khusunya Shinto dengan pelaksanaan festival di Jepang yang berlangsung hampir sepanjang tahun.
\end{abstract}

Kata kunci: agama, festival, tradisional, Shinto, matsuri 


\section{PENDAHULUAN}

Jepang adalah salah satu negara kepulauan yang terletak di benua Asia. Jepang terdiri dari empat pulau utama (Hokkaido, Honshu, Shikoku, dan Kyushu) dan 4000 pulau kecil lain. Luas wilayahnya mencapai $378.000 \mathrm{~km} 2$ dengan jumlah penduduk berjumlah kurang lebih 128 juta jiwa. Wilayah itu dikelilingi dua lautan besar, yaitu lautan Pasifik di sebelah timur dan laut Jepang di sebelah barat serta sejumlah gunung berapi. Jepang dikenal sebagai negara yang memiliki nilai budaya tinggi dan masih terpelihara dengan baik hingga saat ini.

Kebudayaan itu ada yang merupakan kebudayaan asli Jepang dan ada pula yang merupakan perpaduan antara kebudayaan asli dan asing. Salah satunya adalah sistem kepercayaan atau agama (shuukyou). Istilah agama atau shuukyou sendiri mulai populer sejak masa Meiji (1868 1912). Agama utama di Jepang meliputi Shinto, Budha, dan Kristen. Shinto dikatakan sebagai agama alamiah yang lahir dan berkembang sejak zaman prasejarah dan mengalami pengaruh dari Budha dan Kristen.

Mayoritas orang Jepang bersikap sangat toleran terhadap ajaran agama yang ada, termasuk dalam hal melibatkan diri dalam beberapa agama sekaligus. Hal tersebut mungkin dianggap aneh bagi sebagian masyarakat dunia, namun tidak demikian halnya dengan bangsa Jepang. Sikap toleransi itu juga tercermin dalam hal penerimaan terhadap agama yang datang dari luar serta kebebasan dalam mengembangkan aliran agama baru (sekte). Undang-undang negara Jepang menjamin adanya kebebasan beragama di kalangan masyarakat. Selain itu, Jepang tidak mengenal adanya agama negara (state religion) dan tidak ada hubungan di antara kegiatan kenegaraan dan keagamaan. Pendidikan agama pun dilarang diajarkan di sekolah umum.

Fenomena akan kepercayaan beragama di kalangan masyarakat Jepang mulai terbentuk sejak masuknya ajaran Konfusianisme sekitar abad ke-6 dari Cina. Sejak saat itu, ajaran Konfusianisme terus merasuk ke dalam sendi kehidupan, pemikiran, dan pandangan hidup masyarakat Jepang. Hal itu terus bertahan sampai abad ke-19. Masyarakat Jepang dewasa ini bukanlah penganut ajaran Konfusianisme seperti pada era Tokugawa (1603 1868), namun nilai ajaran itu tetap meresap di dalam kehidupan mereka. Pemahaman akan nilai tersebut tetap dipertahankan di tengah penerimaan orang Jepang akan ilmu modern, konsep modern tentang kemajuan dan pertumbuhan, prinsip yang universal, serta cita-cita dan nilai demokratis.

Kebanyakan rakyat Jepang mengambil sikap tidak peduli terhadap agama dan melihat agama sebagai budaya dan tradisi. Bila ditanya mengenai agama, mereka akan mengatakan bahwa mereka beragama Budha hanya karena nenek-moyang mereka menganut salah satu sekte agama Budha. Pada saat ini, Shinto suatu agama yang berasal dari Jepang sudah hampir luput dari perhatian dan hanya diketahui oleh beberapa cendekiawan saja. Kebanyakan ajaran Budha dan Shinto hanya dipraktikkan di dalam ritual kebudayaan, seperti upacara pernikahan, kematian, dan sebagainya. Sejumlah minoritas menganut agama Kristen, Shamanisme, dan agama baru, seperti Soka Gakkai. Sebagian agama baru itu berkaitan erat dengan agama Buddha. Secara faktual, Budha dan Shinto memang agama penduduk Jepang. Hampir di berbagai sudut kota dapat dijumpai kuil tempat beribadah mereka. Hanya anehnya, mereka yang berkunjung dan beribadah di kuil Budha, kebanyakan juga datang beribadah ke kuil Shinto.

Lebih dari itu, biasanya keberagamaan warga Jepang juga dapat terlihat pada tempat sembahyang di dalam rumah. Di daerah pedesaan, tidak jarang ditemui warga yang memiliki tempat sembahyang agama Budha sekaligus agama Shinto di masing-masing rumahnya. Meski kehidupan beragama yang mereka jalani demikian, jangan pernah menganggap mereka tidak percaya pada keberadaan Tuhan. Jika ditanyakan pada mereka tentang Tuhan, hampir dipastikan mereka semua mengakui adanya zat Maha Pencipta. 
Penduduk Jepang, terutama yang lanjut usia, rata-rata menganut dua keyakinan itu sekaligus. Sementara anak muda cenderung tidak peduli pada agama. Apalagi mereka yang tinggal di perkotaan. Kesadaran beragama warga Jepang yang seperti itu, sepertinya juga terkait dengan konstitusi negara mereka. Konstitusi yang dibuat pemerintah AS sebagai pemenang Perang Dunia II, sama sekali tidak menyebut soal kehidupan beragama warga Jepang. Dan hingga kini, konstitusi yang diberlakukan sejak 1946 ini sama sekali belum pernah diamandemen. Dengan dasar konstitusi seperti itu maka sekolah di Jepang sejak sekolah dasar (SD) hingga universitas, tak pernah mecantumkan pendidikan agama. Masalah agama dianggap sebagai urusan pribadi masing-masing warga negara sehingga negara tak perlu mengaturnya.

Bila ditanyakan apa agama warga Jepang maka secara resmi pemerintah Jepang akan menjawab bahwa kebanyakan orang Jepang memeluk agama Shinto dan Budha. Statistik menunjukkan bahwa hanya sedikit orang Jepang yang tertarik pada ajaran agama tertentu. Mayoritas dari mereka menunjukan kecenderungan tidak tertarik pada ajaran agama sama sekali. Ada beberapa alasan yang dapat dikemukakan di sini. Alasan yang pertama adalah bahwa orang Jepang ditakdirkan hidup dalam lingkungan yang nyaman dan aman dari segala gangguan dan bencana sejak beberapa generasi. Hal itu mendorong mereka menjadi sosok manusia yang tidak terlalu peduli terhadap suatu ajaran agama tertentu. Hal lain adalah karena keberadaan ajaran Shinto yang bersifat polytheis sehingga membuat orang Jepang bersikap sangat toleran terhadap segala aliran agama.

Akan tetapi, keadaan itu dapat berubah menjadi kondisi yang kontradiksi, yaitu sosok yang tadinya acuh terhadap agama berubah menjadi sangat tertarik dengan ajaran agama tertentu. Hal itu terjadi apabila individu tersebut sedang mengalami masalah atau pada mereka yang sudah berusia lanjut dan sudah timbul kesadaran untuk lebih mendekatkan diri pada suatu ajaran tertentu.

Istilah shuukyou atau agama di Jepang digunakan dalam konotasi makna yang lebih luas dari istilah agama di Indonesia. Hal itu karena istilah shuukyou mencakup pengertian "agama" dan sekaligus "religi” (Anwar, 2005:3). Seorang tokoh bernama Miyake Hitoshi, dalam salah satu kayanya yang berjudul Nihon Shuukyou no Kouzou atau Struktur Agama Jepang mengemukakan bahwa umumnya para ilmuwan Jepang yang tertarik pada penelitian tentang agama di Jepang membedakan pengertian shuukyou atau agama-agama yang ada di dunia menjadi tiga kategori.

Pertama, 未開宗教 (Mikai shuukyou), yaitu agama yang berkembang di dalam masyarakat primitif, seperti kepercayaan Animisme, Toteisme, dan Shamanisme.

Kedua, 民族宗教 (Minzoku shuukyou), agama yang berkembang dalam bangsa atau suku bangsa tertentu seperti Shinto, Taoisme, dan Konfusianisme.

Ketiga, 世界宗教 (Sekai shuukyou), yaitu agama yang dianut masyarakat dunia atau yang bersifat universal, seperti Islam, Kristen, dan sebagainya (Anwar, 2005:3).

Bagi sebagian besar orang Jepang sulit menjawab dengan tegas apabila ditanyakan mengenai kepercayaan atau agama yang dianutnya. Mereka pada umumnya tidak memiliki satu agama tertentu untuk dianut dan hanya memiliki minat yang kecil atas suatu agama tertentu. Akan tetapi, meski hanya memiliki minat yang kecil terhadap suatu agama tertentu, mereka kerapkali melaksanakan kegiatan yang berhubungan dengan keagamaan, khususnya Shinto dan Budha. Ritual yang dilakukan tersebut berlangsung hampir sepanjang tahun, seperti Obon, Hinamatsuri, Tanabata, Shichigosan, dan sebagainya. Demikian pula dengan upacara pernikahan dan kematian. Acapkali mereka datang ke kuil untuk meminta jimat demi keselamatan atau kesuksesan dalam karir dan sekolah. Hal itu menunjukkan adanya sikap yang kontradiktif di dalam masyarakat Jepang, khususnya dalam hal kepercayaan.

Sikap ambigu dalam kehidupan beragama di Jepang, antara lain disebabkan faktor berikut: Adanya sinkretisme/penyatuan, baik dalam doktrin agama maupun tingkah laku keagamaan masyarakat Jepang; Proses sekularisasi dan pembauran agama Budha di Jepang; Proses pembauran 
agama Shinto yang membaur dengan Budha dan Konfusianisme; Perubahan kebijakan politik negara Jepang terhadap Budha, Shinto, Konfusianisme dan Kristen; Berkaitan dengan membaurnya agama dengan berbagai kepercayaan rakyat Jepang yang semakin berkembang (Anwar, 2005:3).

\section{PEMBAHASAN}

\section{Eksistensi Agama Shinto}

Kata Shinto berasal dari dua kanji, yaitu "shin" 神 yang artinya "dewa" dan to" 道yang artinya "jalan". Dengan demikian, apabila kedua kanji itu digabungkan akan tercipta suatu arti, yaitu "jalan dewa" atau jalan Tuhan. Dari catatan sejarah yang ada, diketahui bahwa agama itu berasal dari India dan masuk ke Jepang secara resmi dari Cina melalui Korea pada tahun 538 masehi (Anwar 2005:4). Agama Shinto dianggap atau dikategorikan sebagai agama asli bangsa Jepang atau juga agama tradisional bangsa Jepang. Pada awalnya, ajaran Shinto dilaksanakan oleh keluarga yang memiliki kekuatan atau yang dikenal dengan nama klan. Agama itu mempercayai bahwa pendiri bangsa Jepang berasal dari surga atau khayangan yang kemudian turun ke bumi dan membentuk negara Jepang sekaligus menjelma ke dalam Tenno atau kaisar. Hal itu menyebabkan adanya pandangan yang mempercayai bahwa tenno adalah titisan dari dewi Amaterasu Oomikami (Saronto, 2005:105).

Sejak masa Restorasi Meiji (1868 1912) hingga akhir Perang Dunia II, Shinto adalah agama resmi di Jepang. Agama Shinto melibatkan penyembahan kami, yang dapat diterjemahkan sebagai dewa, roh alam, atau sekedar kehadiran spiritual. Sebagian kami berasal dari daerah setempat dan dapat dianggap sebagai roh yang mewakili daerah tersebut, namun kami lainnya mewakili benda dan proses alami utama, misalnya Amaterasu, sang dewi matahari. Setelah Perang Dunia II, Shinto kehilangan statusnya sebagai agama resmi. Sebagian ajaran dan kegiatan Shinto yang sebelumnya dianggap penting pada masa perang ditinggalkan dan tidak lagi diajarkan. Sebagian lagi tetap bertahan, namun telah kehilangan konotasi keagamaannya, misalnya dengan penyelenggaraan omikuji (semacam undian untuk menebak keberuntungan).

Agama Budha dan Shinto sebagai agama yang memiliki jumlah penganut terbesar senantiasa berjalan secara rukun, bahkan saling mendukung sehingga masyarakat Jepang pun dapat melaksanakan kedua ritual tersebut secara bersamaan. Shinto bukan merupakan prinsip moral atau doktrin filosofi, melainkan merupakan suatu sistem pemujaan yang muncul secara alami dengan penekanan pada upacara ritual agama (matsuri) yang bersumber dari kehidupn pertanian masyarakat Jepang.

Agama Shinto berkembang bersamaan dengan perkembangan masyarakat pertanian beras. Agama itu berlandaskan pada pemujaan pada dewa padi dan nenek moyangnya. Agama itu mengenal Tuhannya atau dalam bahasa Jepangnya disebut kami sama dan melakukan pemujaan di kuil Shinto atau Jinja. Tidak ada panduan berupa kitab suci maupun pimpinan agamanya. Menurut ajarannya, Tuhan dimiliki oleh semua mahluk hidup sehingga dapat dikatakan bahwa jumlahnya sangat banyak, bahkan tidak terhitung. Hal itu dapat terlihat dalam salah satu mitologi Jepang yang berjudul Yaoyorozu no Kami atau delapan juta Tuhan. Mengenai istilah kami tersebut seorang teolog Shinto dari abad 14, Imbe no Masamichi dalam karyanya Shindai Kuketsu (1367) mengatakan:

Kami (istilah Jepang untuk dewa) berasal dari kata kagami (cermin) yang kemudian disingkat dan dibaca kami. Pikiran Tuhan, seperti sebuah cermin, merefleksikan semua yang ada di alam. Dia bertindak dengan keadilan yang tidak memihak dan tidak menegang setitikpun kotoran. Apa yang ada di langit itulah kami, di alam itulah Ruh dan dalam diri manusia itulah ketulusan. Jika ruh alam dan hati manusia suci dan jernih, maka mereka menjadi kami."

(Bellah, 1992:88). 
Masyarakat Jepang mempercayai bahwa roh mereka tersebut menempati bermacam objek natural yang jumlahnya sangat banyak. Semangat atau spirit akan pemujaan dewa padi tersebut menjadi yang terpenting. Melalui semangat tersebut mereka percaya akan didapatkannya alam lain dan di dalamnya mereka akan mengalami bermacam pantangan yang akan menyucikan mereka kelak. Sehubungan dengan kepercayaan tersebut, mereka pun sering mengadakan bermacam upacara yang berkaitan dengan penanaman padi, baik sebelum maupun sesudah panen. Selain kepercayaan akan dewa padi, semangat akan pemujaan leluhur pun memegang peranan penting dalam kehidupan masyarakat Jepang. Mereka percaya bahwa arwah orang yang telah meninggal akan selalu hadir diantara mereka yang masih hidup.

Mayoritas orang Jepang pergi ke jinja (kuil shinto) pada saat melangsungkan pernikahan, perayaan kelahiran bayi, merayakan kelulusan ujian masuk universitas. Para keluarga biasanya datang pada hari pertama di tahun baru atau hatsumode untuk memohon rahmat kesuksesan dan kebahagian di tahun tersebut. Masing-masing jinja memiliki upacara keagamaannya masing-masing setiap tahunnya. Pada saat itu, umumnya dihadiri oleh masyarakat setempat dan dimeriahkan dengan penjualan berbagai souvenir di depannya. Di jinja itu pun masyarakat dapat meminta atau membeli jimat keselamatan.

Sebagai bagian dari minzoku shuukyoo atau agama yang berkembang dalam masyarakat tertentu, Shinto memiliki beberapa ciri khas sebagai berikut: Shizen hassei tekini seiritsushita shuukyou (agama yang lahir dan berkembang secara alami); Tokutei no kyousou wa inai (tidak ada tokoh tertentu yang dianggap sebagai pendirinya); Kyouri yori saishigirei ga juushisatereiru (lebih mementingkan upacara ritual daripada doktrin keagamaan); Seijiteki gunjiteki shihaisya ga doujini shuukyouteki shihaisya dearu (penguasa pemerintahan baik yang bersifat politis maupun militer, sekaligus menjadi pemimpin keagamaan); Kojin no kyuusai yorimo kyoudotai no rieki ga yuusensareru (lebih memprioritaskan keuntungan yang bersifat kebersamaan ketimbang pribadi) (Anwar, 2005:5).

Shinto dikenal juga sebagai Dentooteki Shuukyoo atau agama tradisional Jepang. Sejak abad ke-19, agama itu diletakkan sebagai agama negara dan kaisar dipuja sebagai dewa. Akan tetapi, sesudah Perang Dunia kedua, pelaksanaan keagamaan diletakkan terpisah dari fungsi kenegaraan dan ritual pemujaan dibatasi di masing-masing kuil tiap daerah.

Dalam perkembangan selanjutnya, sejak zaman Nara (710 794) terjadi pula dinamika konsep kepercayaan yang disebut Shinbutsu Shugo, yaitu perpaduan di antara Shinto dan Budha. Konsep itu bukan berdasarkan pada "pemahaman" orang Jepang terhadap ajaran Budha, melainkan bertolak dari anggapan mereka tentang dewa Budha yang memiliki kekuatan yang sama (identik) dengan dewa Shinto yang telah ada jauh sebelum agama Budha masuk ke Jepang. Hingga pada zaman Heian (794 1185), muncul pula suatu konsep yang disebut Honjisuijyaku yang beranggapan bahwa dewa Budha adalah perwujudan dari dewa Shinto. Hal itu melahirkan sebuah pemahaman bahwa dewa Shinto adalah juga dewa Budha. Manifestasi dari timbulnya konsep Shinbutsu Shugo tersebut antara lain adalah didirikannya jiin (kuil Budha) berdampingan dengan jinja (kuil Shinto), pembangunan jiin di gunung, dan para pendeta budha mulai melakukan shugyo (bertapa di gunung), suatu hal yang berkaitan dengan adanya kepercayaan Shinto terhadap gunung yang dinamakan Sangaku Shinko.

Eksistensi Shinto semakin kuat pada zaman Meiji (1867 1912), ketika kaisar Meiji pada tahun 1868 secara politis menetapkan agama Shinto sebagai agama negara. Hal itu dilakukan untuk memantapkan landasan dasar pemerintah zaman Meiji yang sakral di bawah pimpinan Tenno (kaisar) sehingga negara Jepang pada zaman Meiji dianggap identik dengan negara Shinto (Kokka Shinto) (Anwar, 2005:7). 


\section{Matsuri}

Jepang adalah salah satu negara maju dan modern di dunia saat ini. Kedudukannya sudah dapat disetarakan dengan negara maju lain, seperti di Eropa dan Amerika. Kemajuan yang dialami berawal dengan dilaksanakannya Meiji Isshin atau Restorasi Meiji sekitar tahun 1867-an yang mengubah bentuk negara itu menjadi negara modern. Akan tetapi, sebagai negara yang telah berhasil mencapai kemajuan di hampir semua bidang, Jepang ternyata tidak begitu saja meninggalkan budaya tradisionalnya. Di satu sisi, Jepang telah mengalami modernisasi di hampir seluruh bidang kehidupan, namun di sisi lain bangsa itu tetap mempertahankan keunikan seni tradisionalnya.

Jepang yang kini tumbuh menjadi salah satu negara adidaya di dunia pada awalnya juga mengalami masa sulit dan terbelakang. Sebelum diadakannya restorasi Meiji atau Meiji Isshin, negeri itu menjalankan sistem pemerintahan yang bersifat feodalistik dan penyelenggaraan pemerintahan dipegang oleh kaum militer. Restorasi Meiji menjadi suatu momentum yang sangat penting bagi kemajuan Jepang. Di bawah pemerintahan Meiji, Jepang dengan slogan Fukoku Kyohei mulai membangun ketertinggalannya dalam berbagai bidang kehidupan. Di bidang pendidikan, misalnya, telah dilakukan usaha untuk memodernisasi pendidikan dari yang bersifat tradisional menjadi suatu bentuk pendidikan modern. Adanya pengaruh kebudayaan asing, khususnya Barat membuat pemerintah lebih bersemangat mencari terobosan baru untuk memajukan sektor tersebut.

Peristiwa kedua yang berhubungan dengan pembangunan Jepang terjadi ketika mengalami kekalahan dalam Perang Dunia Kedua yang berakibat hancurnya perindustrian yang baru dibangun. Akan tetapi, dalam kurun waktu yang singkat Jepang berhasil menyamai kedudukannya dalam bidang ekonomi dengan negara barat. Paham demokrasi yang tertera dalam Undang-Undang Showa tampak dalam kehidupan masyarakatnya. Semua anggota masyarakat bebas untuk menentukan pekerjaan sesuai dengan minat dan bakat yang dimiliki. Bervariasinya pekerjaan yang dilakukan oleh setiap anggota keluarga mengakibatkan mereka membentuk keluarga inti dan tinggal terpencar di berbagai wilayah yang ada di Jepang. Hal itu merupakan salah satu bukti sehingga Jepang dapat dikatakan sebagai negara yang mempunyai wajah Barat.

Untuk memahami kemajuan Jepang tidak cukup hanya mengkaji dengan wajah Barat yang ditinjau dari sudut ekonomi, politik, dan teknologinya sebagai perwujudan konkret dari budaya, tetapi juga harus mengkaji hal yang terjadi di balik kemajuan budaya material tersebut. Masyarakat Jepang dikenal sebagai masyarakat yang sangat menjunjung tinggi nilai tradisional. Jepang masih sering disebut sebagai negara yang mempunyai wajah tradisional, yaitu bangsa yang tetap menjalankan budaya tradisional, terutama tampak dalam kegiatan ritual yang masih diselenggarakan oleh masyarakat pedesaan dan perkotaan.

Dalam tradisi masyarakat Jepang, tiada hari tanpa matsuri. Matsuri adalah kata dalam bahasa Jepang yang menurut pengertian agama Shinto berarti ritual yang dipersembahkan untuk kami atau dewa sedangkan menurut pengertian sekularisme berarti festival, perayaan, atau hari libur perayaan. Matsuri bagi orang Jepang dianggap sebagai salah satu simbol dari kegiatan manusia untuk berkomunikasi dan melayani dewa. Dengan kata lain, matsuri bagi orang Jepang dianggap sebagai jalan untuk bertemu dengan dewa.

Ada dua pendapat yang berbeda sehubungan dengan penyelenggaran matsuri. Pertama adalah matsuri menurut Yanagita (1982). Menurutnya, dari kurang lebih 50.000 matsuri sepanjang tahunnya dapat dibagi dalam tiga kategori. Pertama, Tsukagirei. Matsuri yang dilakukan orang Jepang sepanjang hidupnya sejak janin hingga menjadi arwah. Perpindahan dari satu tahap ke tahap lain dianggap mengandung bahaya sehingga harus diadakan upacara untuk menangkalnya. Kedua, Nenchuugyouji. Upacara yang dilakukan secara periodik dan pada waktu yang telah ditetapkan setiap tahunnya menurut penanggalan Jepang. Ketiga, Ninigirei. Upacara yang dilakukan secara aksidental karena adanya peristiwa yang terjadi dalam hidupnya. 
Pendapat lainnya adalah yang dikemukakan oleh Hirosachiya yang membuat kategori matsuri yang agak berbeda. Menurutnya, berbagai macam matsuri yang ada dalam Shinto dapat digolongkan menjadi tiga.

Pertama，神社における祭し Matsuri yang diadakan di jinja (kuil).

Kedua，宮廷における祭し Matsuri yang diadakan di istana.

Ketiga，民間における祭し Matsuri yang dilakukan di kalangan rakyat biasa (Anwar, 2005:6).

\section{Sejarah Matsuri}

Matsuri berasal dari kata matsuru ( menyembah, memuja) yang berarti pemujaan terhadap kami atau ritual yang terkait. Dalam teologi agama Shinto dikenal empat unsur dalam matsuri: penyucian (harai), persembahan, pembacaan doa (norito), dan pesta makan. Matsuri yang paling tua yang dikenal dalam mitologi Jepang adalah ritual yang dilakukan di depan Amano Iwato.

Matsuri dalam bentuk pembacaan doa masih tersisa, seperti dalam bentuk kigansai (permohonan secara individu kepada jinja atau kuil untuk didoakan) dan jichinsai (upacara sebelum pendirian bangunan atau konstruksi). Pembacaan doa yang dilakukan pendeta Shinto untuk individu atau kelompok orang di tempat yang tidak terlihat orang lain merupakan bentuk awal dari matsuri.

Pada saat ini, Ise Jingu merupakan salah satu contoh kuil agama Shinto yang masih menyelenggarakan matsuri dalam bentuk pembacaan doa yang eksklusif bagi kalangan terbatas dan peserta umum tidak dibolehkan ikut serta. Sesuai dengan perkembangan zaman, tujuan penyelenggaraan matsuri sering melenceng jauh dari maksud matsuri yang sebenarnya. Penyelenggaraan matsuri sering menjadi satu-satunya tujuan dilangsungkannya matsuri sedangkan matsuri hanya tinggal sebagai wacana dan tanpa makna religius.

Dalam bahasa Jepang, kata "matsuri" juga berarti festival dan aksara kanji untuk matsuri (祭) dapat dibaca sebagai sai sehingga dikenal istilah seperti Eiga-sai (festival film), Sangyō-sai (festival hasil panen), Ongaku-sai (festival musik), dan Daigaku-sai (festival yang diadakan oleh universitas). Shimin Matsuri adalah sebutan untuk matsuri yang diselenggarakan pemerintah daerah atau kelompok warga kota dengan maksud untuk menghidupkan perekonomian daerah dan umumnya tidak berhubungan dengan institusi keagamaan.

\section{Pengaruh Shinto dalam Pelaksanaan Matsuri}

Matsuri diadakan di banyak tempat di Jepang dan pada umumnya diselenggarakan jinja atau kuil Shinto dan dipimpin oleh pendeta Shinto atau kanushi, walaupun ada juga matsuri yang diselenggarakan gereja dan matsuri yang tidak berkaitan dengan institusi keagamaan. Di daerah Kyushu, matsuri yang dilangsungkan pada sebagian besar matsuri diselenggarakan dengan maksud untuk mendoakan keberhasilan tangkapan ikan dan keberhasilan panen, seperti beras, gandum, kacang, jawawut, jagung, dan sebagainya. Matsuri juga sering dikaitkan dengan kesuksesan dalam bisnis, kesembuhan dan kekebalan terhadap penyakit, keselamatan dari bencana, dan sebagai ucapan terima kasih setelah berhasil dalam menyelesaikan suatu tugas berat.

Matsuri juga diadakan untuk merayakan tradisi yang berkaitan dengan pergantian musim atau mendoakan arwah tokoh terkenal. Makna upacara yang dilakukan dan waktu pelaksanaan matsuri beraneka ragam seusai dengan tujuan penyelenggaraan matsuri. Matsuri yang mempunyai tujuan dan maksud yang sama dapat mempunyai makna ritual yang berbeda tergantung pada daerahnya. Masyarakat Jepang hampir setiap hari menyelenggarakan matsuri, baik yang berhubungan dengan agama maupun kepercayaan yang dianut, maupun ritual yang tidak berhubungan dengan salah satu agama atau kepercayaannya. Matsuri adalah suatu upacara keagamaan yang bermaksud untuk berada di samping kami (dewa) atau upacara yang mendatangkan dewa guna mendekatkan diri pada dewa. 
Kegiatan matsuri pada hakikatnya merupakan suatu kegiatan untuk mengundang dewa atau duduk di samping dewa, seperti yang djelaskan oleh Yanagita (1982:42) dan diterjemahkan "berada di samping dewa”. Mungkin dengan istilah lain dapat juga dikatakan melayani dewa tetapi sebagai wujud konkretnya matsuri adalah suatu sikap menyambut kehadiran dewa, dengan menyajikan segala sajian yang ada dan dengan menunjukkan sikap mengabdikan diri pada dewa. Matsuri bukan berarti hanya menunjukkan penghormatan terhadap dewa dari kejauhan. Penjelasan Yanagita ini dapat disimpulkan bahwa matsuri merupakan upacara keagamaan yang bermaksud untuk berada di samping kami (dewa) atau dapat dikatakan sebagai upacara yang mendatangkan dewa guna mendekatkan diri pada dewa dengan menyajikan sajian suci yang dilakukan oleh Pendeta Shinto.

Pengertian matsuri sesungguhnya merupakan upacara keagamaan untuk mengundang atau mendatangkan dewa atau peristiwa terjadinya pertemuan antara manusia dan dewa dengan tujuan untuk mendapatkan petunjuk dan berkah. Matsuri merupakan perilaku keagamaan orang Jepang, yaitu upacara keagamaan untuk menghormati dewa dan merupakan perwujudan kepercayaan orang Jepang yang tidak dapat dipisahkan dari kehidupan sehari-harinya. Tidak ada jalan lain menuju jalan dewa, kecuali menempuh satu-satunya jalan, yaitu matsuri. Melalui matsuri masyarakat Jepang merasakan akan kehadiran dewa dalam kehidupan dan matsuri dianggap sebagai kepercayaan bangsa Jepang. Umumnya, baik tua maupun muda, masyarakat Jepang akan melaksanakan salah satu dari kegiatan matsuri itu secara periodik.

Pada umumnya, upacara itu mulai dilakukan pada malam hari dengan menyajikan yumike, yaitu sajian malam khusus untuk dewa dan akan berakhir pada pagi hari dengan sajian asamike, yaitu sajian pagi sehingga upacara itu akan berlangsung selama dua hari satu malam. Dalam menyelenggarakan matsuri, ada beberapa faktor yang harus diperhatikan. Pertama, Sao. Sao adalah tiang yang ditegakkan di suatu tempat sebagai tanda bahwa di tempat itu akan diselenggarakan matsuri.

Selain itu juga, sao dianggap sebagai tangga tempat turun naiknya dewa yang akan hadir pada saat matsuri. Bentuk sao ada bermacam-macam, yaitu sao pohon, sao tongkat, sao nisan kuburan, sao tiang, dan sao campuran antara pohon dan tiang. Namun saat ini, sao tongkat yang lebih banyak digunakan karena pohon yang akan dijadikan sao pohon sulit ditemukan yang memenuhi syarat. Sao biasanya diletakkan di altar kuil atau halaman kuil tempat diselenggarakannya. Kedua, Mono imi. Mono imi adalah proses penyucian diri yng dilakukan sebelum melaksanakan matsuri. Hal itu dilakukan karena melaksanakan matsuri, segala sesuatu harus dijauhkan dari segala macam unsur kotor. Mono imi biasanya dilakukan oleh para toya, yaitu pemimpin upacara ritual dalam matsuri itu sebagai orang yang bertanggungjawab atas penyelenggaraan matsuri.

Selain kedua faktor itu, ada lima faktor lain yang harus dipersiapkan dalam menyelenggarakan matsuri. Pertama, shinchi, yaitu faktor yang berkaitan dengan penempatan dewa sebagai objek pemujaan dalam matsuri. Kedua, shinya, yaitu faktor yang berkaitan dengan orang yang berperan dalam penyelenggaraan matsuri yang disebut dengan toya. Ketiga, shintai atau kamizawa, yaitu sektor yang berkaitan dengan kegiatan penyambutan dewa yang menjadi objek pemujaan dalam matsuri. Keempat, sekku atau sechi, yaitu sajian suci untuk dewa dan yang ini berkaitan dengan sajian suci yang akan dipersembahkan kepada dewa. Kelima, saijitsu, yaitu penentuan waktu untuk pelaksanaan matsuri.

Ada dua cara dalam menentukan waktu penyelenggaraan, yaitu berdasarkan penanggalan perputaran matahari atau yang disebut dengan penanggalan masehi dan cara yang kedua berdasarkan sistem penanggalan Cina yang disebut dengan sistem penanggalan kanshi. Pelaksanaan matsuri biasanya diselenggarakan pada malam hari, khususnya dilaksanakan ketika munculnya bulan purnama. Salah satu unsur lain dalam penentuan waktu, yaitu matsuri biasanya diselenggarakan pada pergantian musim. 
Bagi masyarakat Jepang, matsuri merupakan perwujudan perilaku keagamaan orang Jepang, khususnya agama Shinto. Pengaruh agama Shinto sangat jelas terlihat dalam setiap pelaksanaan ritual matsuri tersebut. Hal itu dapat terlihat dari tempat pelaksaannya di jinja (kuil shinto), pemimpin upacaranya, yaitu kanushi (pendeta Shinto). Akan tetapi, matsuri bukan merupakan bentuk agama orang Jepang karena tidak terdapat kitab suci yang mengajarkan ajarannya sebagai salah satu faktor yang harus dimiliki suatu agama, tidak memiliki pemuka agama atau nabi, tidak ada misi penyebaran dan tidak memiliki kelompok atau komuniti yang resmi. Pengikut matsuri tidak dicatat secara resmi dalam daftar keanggotaan suatu kelompok agama. Matsuri merupakan suatu event yang memberi kesempatan untuk mendidik atau mengajarkan etika keagamaan.

Dalam penyelenggaraannya, dilakukan prosesi atau arak-arakan Mikoshi. Mikoshi adalah replika kuil yang dibawa secara bersama-sama. Acara matsuri diawali dengan ritual pengambilan mikoshi di jinja (kuil) kemudian diarak keliling kota. Acara puncak matsuri pada hari minggu malam dan mikoshi dan segala peralatannya dikembalikan lagi ke kuil setelah melakukan ritual matsuri, dan disimpan kembali hingga tahun yang akan datang. Mikoshi dikenal juga dengan nama dashi (danjiri) dan yatai yang semuanya merupakan nama kendaraan berisi Kami atau objek pemujaan. Pada matsuri juga dapat dijumpai chigo (anak kecil dalam prosesi), miko (anak gadis pelaksana ritual), tekomai (laki-laki berpakaian wanita), hayashi (musik khas matsuri), penari, peserta, dan penonton yang berdandan dan berpakaian bagus serta pasar kaget beraneka macam makanan dan permainan.

Matsuri yang berjumlah ribuan itu dapat ditemui di hampir seluruh pelosok negeri Jepang. Masing-masing memiliki makna dan keunikan tersendiri. Keberadaannya sangat menarik perhatian, terutama bagi bangsa lain di dunia. Keberadaan matsuri ternyata tidak hanya sekedar memiliki makna perayaan ritual kebudayaan semata, melainkan juga membuktikan eksistensi pengaruh Shinto yang cukup besar dalam setiap pelaksanaannya. Hal itu juga sekaligus membuktikan adanya penghormatan yang besar dari bangsa Jepang sebagai salah satu bangsa modern di dunia terhadap kebudayaan dan kepercayaan tradisionalnya.

\section{PENUTUP}

Kehidupan beragama masyarakat Jepang kerapkali membingungkan sebagian besar orang, khususnya orang asing. Kuil Shinto dan kelenteng Budha terdapat dimana-mana. Mereka acapkali menjalankan ritual keagamaan, upacara pernikahan, kematian, kelahiran yang berhubungan dengan kedua agama tersebut. Akan tetapi, meskipun sebagian besar orang Jepang memasuki satu atau beberapa lembaga keagamaan, mereka tidak menganggap dirinya menganut suatu agama tertentu.

Dalam pelaksanaan sistem kepercayan ini, masyarakat Jepang juga sering mengaitkannya dengan pelaksanaan matsuri sebagai bagian dari ritual kebudayaan, khususnya dengan ajaran Shinto. Pengaruh Shinto dalam matsuri terlihat dalam berbagai ritual di dalamnya, seperti tempat pelaksanaannya di Jinja (kuil Shinto), pemimpin upacaranya, yaitu Kanushi (pendeta Shinto), serta prosesi acaranya yang banyak mengambil unsur agama Shinto. Hal itu akan menjadi semakin menarik karena ternyata di balik fenomena masyarakat yang begitu modern, maju, dan menjadi salah satu simbol kemajuan teknologi dunia, Jepang ternyata sangat memegang teguh nilai tradisional mereka. 


\section{DAFTAR PUSTAKA}

Anwar, Etty N. 2005. Eksistensi Agama Tradisional dan Agama Baru di Jepang. Jakarta: Pusat Studi Jepang.

Ashkenazi, Michael. 1993. Matsuri: Festivals of a Japanese Town. Honolulu: University of Hawaii Press.

Bellah, Robert N. 1992. Religi Tokugawa. Akar-Akar Budaya Jepang. Jakarta: PT Gramedia Pustaka Utama.

Lawanda, Ike Iswari. 2005. Matsuri. Upacara Sosial dalam Masyarakat Jepang. Jakarta: Wedhatama Widya Sastra.

Osumi, Kazuo. 1992. Nihonno Kokoro I. Tokyo: Maruzen Co. Ltd.

Reischauer, Edwin O. 1982. Manusia Jepang. Jakarta: Sinar Harapan.

Saronto, Budi. 2005. Gaya Manajemen Jepang Berdasarkan Azas Kebersamaan (Shuudan Shugi) dan Keakraban (Onjooshugi). Jakarta: Hecca Mitra Utama.

Smith, Warren W. Jr. 1973. Confusianism in Modern Japan. Tokyo: The Hokuseido Press.

Yanagita, Kunio. 1982. Nihon no Matsuri. Tokyo: Kado Kawa Bundo. 